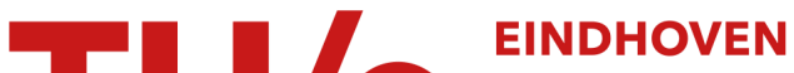 UNIVERSITY OF TECHNOLOGY
}

\section{Application of smart grid technologies in developing areas}

\section{Citation for published version (APA):}

Klaassen, E. A. M., Asare-Bediako, B., Kling, W. L., \& Balkema, A. J. (2013). Application of smart grid technologies in developing areas. In Proceedings of the IEEE Power \& Energy Society General Meeting, July 21-25, 2013, Vancouver, Canada (pp. 1-5). Institute of Electrical and Electronics Engineers. https://doi.org/10.1109/PESMG.2013.6672988

DOI:

10.1109/PESMG.2013.6672988

Document status and date:

Published: 01/01/2013

\section{Document Version:}

Publisher's PDF, also known as Version of Record (includes final page, issue and volume numbers)

\section{Please check the document version of this publication:}

- A submitted manuscript is the version of the article upon submission and before peer-review. There can be important differences between the submitted version and the official published version of record. People interested in the research are advised to contact the author for the final version of the publication, or visit the $\mathrm{DOI}$ to the publisher's website.

- The final author version and the galley proof are versions of the publication after peer review.

- The final published version features the final layout of the paper including the volume, issue and page numbers.

Link to publication

\section{General rights}

Copyright and moral rights for the publications made accessible in the public portal are retained by the authors and/or other copyright owners and it is a condition of accessing publications that users recognise and abide by the legal requirements associated with these rights.

- Users may download and print one copy of any publication from the public portal for the purpose of private study or research.

- You may not further distribute the material or use it for any profit-making activity or commercial gain

- You may freely distribute the URL identifying the publication in the public portal.

If the publication is distributed under the terms of Article 25fa of the Dutch Copyright Act, indicated by the "Taverne" license above, please follow below link for the End User Agreement:

www.tue.nl/taverne

Take down policy

If you believe that this document breaches copyright please contact us at:

openaccess@tue.nl

providing details and we will investigate your claim. 


\section{Application of Smart Grid Technologies in Developing Areas}

\author{
E.A.M. (Elke) Klaassen, Ballard Asare-Bediako, \\ and Wil L. Kling \\ Electrical Energy Systems Group \\ Eindhoven University of Technology \\ Eindhoven, The Netherlands
}

\begin{abstract}
The United Nations has set the ambitious goal of assuring universal access to modern energy by 2030 . Nowadays there are a lot of technical opportunities available to achieve these goals in an efficient way using smart grid technologies. However the extent to which these technologies are being applied in developing areas is still limited, but growing. In this paper this is illustrated taking Angola as example. The energy strategy in Angola is analyzed, focusing on the applications and the opportunities of smart grid technologies in this context, and describing the role of the government and private sector in this field. Lighting, one of the first applications used after access to electricity, is an important factor in the design of local electricity grids. New lighting technologies can increase grid reliability while ensuring safe and secure lighting. The opportunities and applications of smart lighting solutions in Angola are investigated in this paper as well.
\end{abstract}

Index Terms--Distributed power generation, energy efficiency, micro-grids, peak shaving, rural areas, smart grids.

\section{INTRODUCTION}

In 2009,585 million people had no access to electricity in sub-Saharan Africa. This figure is expected to rise to 652 million in 2030. This year is launched as the International Year of Sustainable Energy for All, by the United Nations' Secretary General, which has set the ambitious goal of assuring universal access to modern energy by 2030 [1]. To meet this goal the region needs to develop an extensive electrical infrastructure as can be concluded from Fig. 1. Therefore governments, private sectors and civil societies are called to expand access, improve efficiency and increase the use of renewables. In the recent years access to energy has become an important constituent, if not an essential means, of achieving the Millennium Development Goals [2]. There are several development links to creating access to (electrical) energy [2]. Rural and (sub-) urban electrification benefits the poor, it improves economic and social well-being, and it assists in reducing rural-urban migration and thus in the alleviation of urban congestion and its associated social consequences such as poverty and crime [2]-[3]. Furthermore, better lighting and refrigeration, generates social benefits such as improved health, enhancement of literacy, general

\author{
Annelies J. Balkema \\ Innovation Sciences Department \\ Eindhoven University of Technology \\ Eindhoven, The Netherlands
}

education and social cohesion, and development in communities [3]. Concluding, access to (electrical) energy is considered as a necessary catalyst for development, and therefore a key factor in poverty reduction.

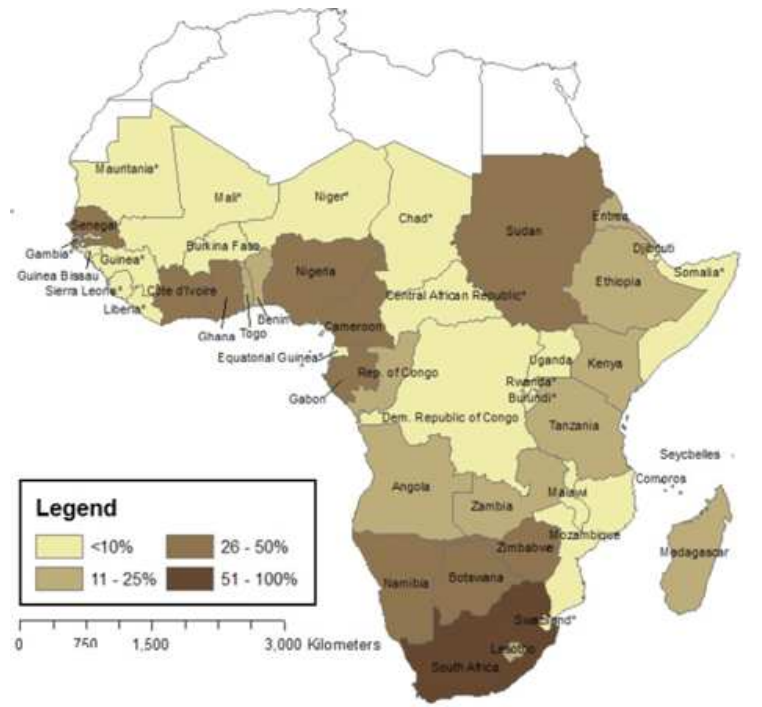

Fig. 1. Percent of population with access to electricity in sub-Saharan Africa, based on information of OECD, IEA (2006) and U.S. International Trade Commission (2009).

Taking into account the costs related to distance, difficulty of landscape and the low $\mathrm{kWh}$ consumption of households in rural areas, investments and payback times for connections to the national electricity system of remote areas in sub-Saharan areas are too high or even impossible [2]. As a consequence, if the classical model is followed, rural areas are not likely to be connected to the national grid in the near future. Therefore local micro-grids are expected to play an important role in electrification strategies in developing countries. Studies already show that autonomous micro-grids are economically feasible and provide a good business opportunity [1]-[4]-[5]. Furthermore micro-grids in developing areas offer additional benefits compared to connecting to the main grid, such as the ability to provide independent electricity supply, reduced transmission losses, the possibility to establish the grid with 
smart features and facilitate the integration of renewable energy sources [5].

In developed countries smart grids with embedded intelligent control, enabling more flexible and efficient operation of electricity grids, are being developed in order to facilitate the energy transition. This transition is typically characterized by two developments in the power sector in the coming decades: (i) the amount of distributed (renewable) generation will increase, (ii) there will be an increasing electrification of energy consumption, due to an expected widespread introduction of (energy efficient) technologies such as electric vehicles and heat pumps. These smart grid technologies may offer an important contribution to universal access to electricity in sub-Saharan Africa [6]. Developing countries have the potential to leapfrog the traditional power systems in terms of both technology and regulation [6], the same way they did with telecommunication.

For illustration, in this paper the current situation in the power sector and the energy strategy in Angola is analyzed, focusing on the applications and the opportunities of smart grid technologies, and describing the stakeholders active in this field. Using literature review, policy documents and interviews with stakeholders active in the Angolan power sector, the paper considers specific smart grid applications that could be implemented in Angola in the short-term. As lighting plays an important role in the design of local electricity grids the opportunities and applications of smart lighting are considered and illustrated in this paper as well.

\section{ELECTRICAL INFRASTRUCTURE AND ENERGY STRATEGY OF ANGOLA}

\section{A. Electrical Infrastructure}

Together with Nigeria, Angola is one of the few oil producing countries in Africa. The income of oil gives the country huge opportunities for infrastructure development. Mainly due to the hike in Angola's export of oil, economists have projected around 10\% GDP growth for Angola in 2012 [7]. Since 2002 there are substantial investments in the electricity sector to restore and reconstruct the infrastructure that was destroyed during the civil war (1975-2002) [8]. However increased investments in the electrical infrastructure have not necessarily translated into widespread electrification. As of 2008 little more than $30 \%$ of the population benefits from access to electricity, coming from Table 1. Due to the displacement of population during the civil war urban congestion is a problem. In the capital Luanda almost five million people live, which is around one-third of the total population. Luanda consumes about two-third of the nation's available electricity, suggesting high access in urban and sub-urban areas and low rural access, as can also be concluded from Fig. 2. Also shown in Fig. 2 is that Angola lacks a national power grid, let alone regional interconnections. There are three relatively large isolated power systems, with minimal local transmission links. The share of hydropower is large, $76 \%$ of the $1,003 \mathrm{MW}$ is coming from hydro plants [10]. The rest is coming from thermal and gas. There is a lot of yet unexploited hydro potential in Angola, as well as abundant gas reserves, estimated at 10 trillion cubic feet [8].

TABLE I

Key FigURES OF ANGOLA's POWER INFRASTRUCTURE, BASED ON 2011 [8].

\begin{tabular}{c|c|c}
\hline Access to electricity (national) & \% of population & 30 \\
\hline Installed capacity per capita & MW per million people & 70 \\
\hline Firms with own generator & \% of firms & 68 \\
\hline Outages per year & Days & 36 \\
\hline Outages, value lost, annually & \% of sales & 13 \\
\hline $\begin{array}{c}\text { Collection rate, reported by } \\
\text { utility, electricity }\end{array}$ & \% of billing & 42 \\
\hline Cost-recovery ratio, historical & \% & 15 \\
\hline Revenue per unit & c $\$ / \mathrm{kWh}$ & 2.5 \\
\hline System losses & \% of generation & $18-23$ \\
\hline Total hidden costs & \% of revenue & 375 \\
\hline
\end{tabular}

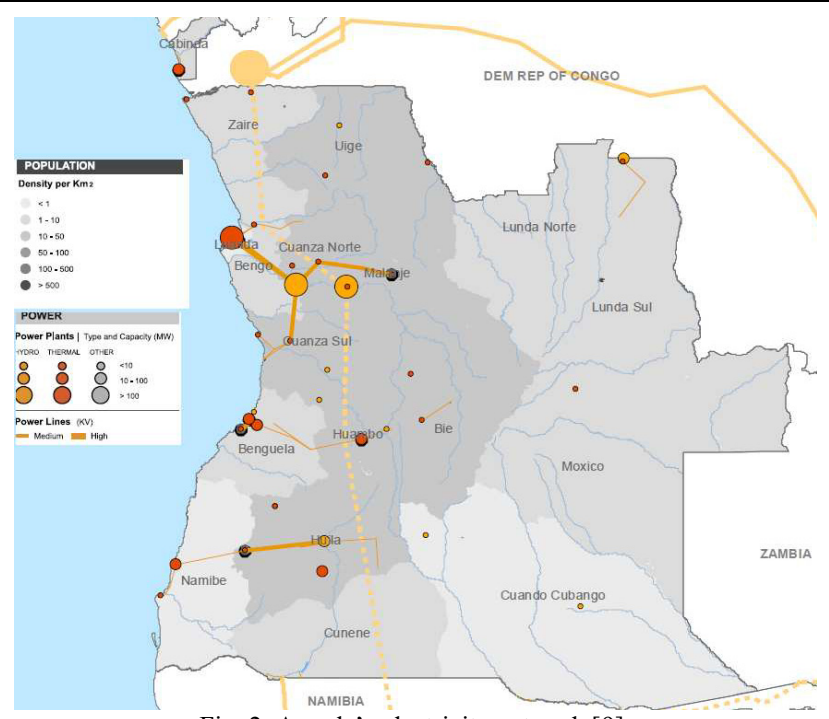

Fig. 2. Angola's electricity network [9].

B. Applying Smart Grid Technologies in order to increase Grid Reliability and Security

As indicated in [4]-[6], most aspects listed in Table 1 stimulate smart grid developments.

- Unreliable electricity supply: load in Angola is generally higher than supply, which leads to power failures and load shedding. Outages per year are over 36 days (Table 1), and it is estimated that in 2008 only $50 \%$ of existing annual power demand was met by the power grid, the balance coming from self-generation [11]. Not surprisingly, $68 \%$ has a back-up diesel generator, resulting in an expensive double, inefficient, and polluting energy supply system.

- Loss reduction: system losses are high; Angola's transmission and distribution losses are estimated to be $18-23 \%$. Smart grid technologies are expected to help minimizing technical losses in transmission, e.g. by facilitating more effective reactive power compensation and voltage control. Distribution losses can be addressed through adaptive voltage control at substations and line drop compensation to level feeder voltages based on the load [6]. 
- Managing data and billing: improper meter reading or faulty meters, leads to significant financial loss, indicated in Table I. More knowledge on electricity usage is required as most statistics in Angola are incomplete and/or outdated [12]. Statistics on self-generation in major urban areas, and on generation, transmission and distribution by provincial and municipal governments are lacking [12]. To increase both information and billing management, placing smart or pre-paid electricity meters is an important step towards a smart grid.

- Peak load management: smart grid technologies have the potential to meet peak load demand by intelligent load control, either through direct control or economic pricing incentives that are communicated to consumers in a dynamic matter. For the latter, placing smart meters is an essential first step. They enable switching off appliances remotely, e.g. peak loads can effectively be reduced by turning on/off thermal loads for short periods of time. Especially the load control potential of air conditioning systems in Luanda is enormous. Almost every room is equipped with such a system. Load control can also be applied for smart street lighting systems, these can be dimmed during periods in which no full lighting capacity is required, while ensuring safe and secure lighting. Peak load management will also reduce the need for operating reserves. In South Africa the importance of load control, in order to enable a secure source of supply, is already recognized [13], and commercial technologies are now available on the market.

- Renewable energy: renewable energy sources such as Photovoltaic (PV) systems offer many possibilities to design micro-grids in rural and remote areas. Especially in micro-grids with an intermittent source of supply, load control plays an important role in the system design. Load control can be used to match supply and demand, for both congestion and imbalance management.

\section{Energy Strategy in Angola}

Due to a fast growing peak demand, substantial investments done in the electricity sector have not translated into widespread electrification of Angola. However the government is aware of the problems concerning access to (reliable) electricity, and is stating to be ready to make the investments and the effort to build out the network [11]-[14]. Within the government it is mainly the Ministry of Energy and Water (MINEA) who is responsible for this. Nowadays there is a director for Renewable Energy within MINEA, indicating that sustainability is also on the agenda of the government. Next to MINEA the main public stakeholders in the power sector are the national power company, Empresa Nacional de Electricidade (ENE), and the distribution system operator in Luanda, Empresa de Distribuição de Electricidade de Luanda (EDEL).

Goal of the government is to reach an electrification rate of $50 \%$ to $60 \%$ in 2025 , which requires investments of 13 billion dollars [11]. Most concrete plans on adding production and transmission capacity focus on the infrastructure in 2016. Long term plans are based on exploiting more the potential of hydropower, especially in the Kwanza River, as the construction of a new hydro plant requires at least five years. Short term plans are based on adding thermal generators, which can be operational within one year.

To enable increasing electrification, the Angolan government is opening up the electricity sector for competition. The government is reorganizing the state-owned utility ENE. The monopoly that ENE has will end and the company will be broken into different business units for generation, transmission and distribution. Through the liberalization the government wants to stimulate PublicPrivate Partnerships (PPPs) for generation and transmission. However liberalization is going slow; plans were already mentioned in 2006 [12] and nowadays there is still not much progress on the liberalization of the sector. The structure of ENE has not changed and the utility still receives direct subsidies from the government, as well as implicit subsidies through low fuel prices.

Most projects of the government are based on tendering, e.g. MINEA, ENE or EDEL give tenders for the (re-) construction of (part of) the grid. Nowadays the general strategy of the government is based on empowerment of the local market, instead of import from foreign MNCs, as was the case in the last decade. Therefore local production is stimulated through taxes discounts.

When it comes to rural electrification MINEA is aware of the importance of micro-grids. Stated in the energy policy is the following [12]: 'In isolated networks, renewable energy may be the most interesting alternative, not only from the perspective of sustainability, but also from an economic perspective and the short time needed to ensure the supply to the population'. At the moment general plans on rural electrification [12] are translated into concrete projects. Isolated PV systems are already installed at rural schools and hospitals $(<5 \mathrm{~kW})$, and micro-grid projects based on PV generation are upcoming. The budget plans for 2012 show the available budget for the construction of these systems [14]. Micro-hydro and wind projects are upcoming, a $100 \mathrm{MW}$ onshore wind farm tender was closed in September 2012, for micro-hydro there are no concrete plans yet.

Due to a growing market for rural electrification, more companies active in the field of renewable energy systems, especially PV systems, are establishing themselves in Angola. Knowledge and technology for the design of the system is most of the times still imported from abroad. Isolated PV systems are mainly based on combining the inverters with battery systems in order to enable energy storage when production exceeds load and the other way around. Load control is not yet applied.

Since 2002 the knowledge sector in Angola had major development, shifting the problem of quantity of education to quality of education. There are two universities specialized in the electricity sector, one public and one private. The public university is getting more funding from the government in order to increase knowledge in the electricity sector. The private university is making important steps into 
collaborating with private (western) companies in order to absorb knowledge and experiment with renewable generation.

To increase data and billing management in the electricity sector EDEL is placing more electricity meters, of which an increasing number of pre-paid meters. However the installation of smart meters is still limited. To increase further implementation of smart meters in Angola a starting point can be similar to the Electricity Regulations Act of 2006 in South Africa: all end users using $1000 \mathrm{kWh}$ or more in a month must have a smart meter system installed by 2012 .

\section{ROlE OF SMART Lighting TeChNOLOGIES IN THE ENERGY TRANSITION}

To tackle the problem of availability of supply, energy efficiency measures can also play an important role. Lighting is one of the first applications used after access to electricity, in [5] the absolute minimum electricity demand for households is quantified by two lighting sources and one mobile phone charger. (Public) lighting plays an important role in the design of (micro-)grids [3]-[4]-[5]. Therefore smart lighting solutions are proposed in the context of increasing grid reliability, peak load management and optimizing the operation of micro-grids.

For smart lighting solutions LED technology is considered, which is $30 \%-80 \%$ more efficient than commonly used lighting technologies in Angola. Having a 5 to 6 times longer lifetime, the usage of LEDs reduces the replacement and maintenance costs. Also LEDs are more suitable for lighting control and for DC applications, e.g. PV applications.

By replacing conventional outdoor and indoor lamps with LED systems the (peak) load in Angola can effectively be reduced by $11.6 \%$. To illustrate the impact Fig. 3 is used to make a distinction between electricity consumption in different areas.

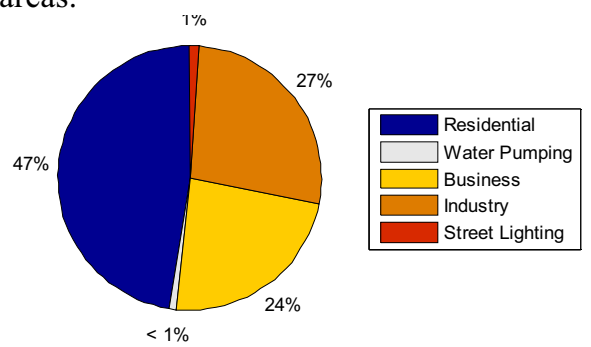

Fig. 3. Pie chart based on electricity consumption in Angola, 2009 [10].

Shown in Fig. 3 is that street lighting in Angola is still limited, contributing only $1 \%$ to the total load. While the average contribution of street lighting is around 6\% [15]. Therefore LEDs can also contribute to future energy savings, by leapfrogging public lighting expansion with conventional outdoor lighting systems. To show the impact of LED applications the focus is on the north part of the grid in Angola (Fig. 2). Here the production capacity is $797 \mathrm{MW}$ [10]. As load generally exceeds production capacity in this area the peak load is assumed to be equal to the production capacity. For outdoor lighting it is assumed that conventional lighting sources, i.e. HPS $80 \mathrm{~W}$ SON lamps, are being replaced by Philips 27W Fortimo LED modules. For indoor lighting only residential households are considered, and it is assumed that $20 \%$ of the electricity consumption is based on lighting. Here $60 \mathrm{~W}$ incandescent light bulbs are being replaced by Philips $12 \mathrm{~W}$ Endura LED lamps. The approach of determining the impact of the usage of LEDs on the load is based on [15] where the impact of standalone PV LED lighting systems is studied for the Egyptian case. Standalone systems consist of a PV panel, battery, LED module, power conditioning system and a controller which manages the power direction and system operation [15]. Using PV LED standalone systems, streets can be illuminated with lower power lamps, with no operating costs, no $\mathrm{CO}_{2}$-emissions and without grid connection [15]. The latter is of importance as this will lower the peak load and increase grid reliability. Fig. 4 shows the impact of LEDs on an assumed load curve in the north part of the electricity system in Angola.

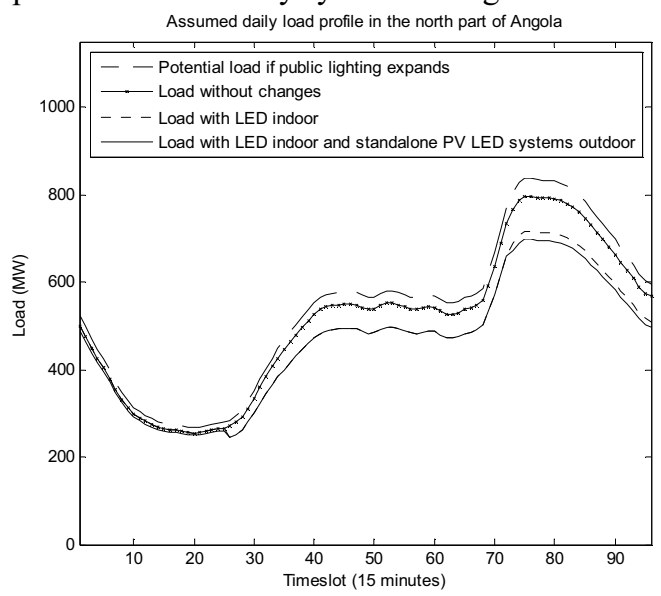

Fig. 4. Impact of LED applications indoor and outdoor on the assumed load curve in the north part of Angola.

Replacing conventional lighting sources by LEDs or standalone PV LED systems has besides reducing the need for production capacity the following advantages:

- Resistance against power and voltage variations: contrary to e.g. HPS lamps, the lifetime of LEDs is less affected by recurrent current cuts and large voltage variations. LEDs are also better for security: HPS e.g. needs start-up time and waiting time between turning on/off the lamp. LED systems give lighting instantaneously when under the allowable tension range.

- Controllable load: it is possible to dim LEDs, reducing the energy demand during periods in which no full lighting capacity is required, and increasing the overall energy efficiency.

- Ensuring safe and secure lighting: frequently load shedding is applied during time periods when there is no daylight, and as back-up diesel generators are often not a solution for street lighting, streets remain dark. Decreasing business activity and increasing crime rates. Standalone PV LED systems have the advantage of providing lighting also in case of grid related black-outs.

- Grid connected areas with no outdoor lighting: in the massive suburbs of e.g. Luanda there are still a lot of areas where there is no public lighting, although there are (illegal) grid connections. It is unlikely that grid 
connected street lighting systems will be installed in these areas, as this will increase the grids' load and then problems related to management of the (peak) load. Installing standalone PV LED systems is an easier, sustainable and safe way to bring public to those areas previously not served.

- Lighting in micro-grids: micro-grids can be weakly regulated grids, i.e. due to the intermittent nature of renewable energy sources. On top of reducing the systems' load, using LEDs in combination with microgrids has two advantages: (i) when designed in the right way LEDs are less sensitive to voltage fluctuations, decreasing luminous flux fluctuations, compared to e.g. HPS systems [16], and (ii) designed under the proposed methodology of [16] LEDs have a smart load nature, the load demand follows the same profile as that of the renewable power generation. Automatic load shedding of the LEDs has the potential of reducing energy storage requirements for balancing power in a micro-grid [16].

The energy saving potential that can be gained using LED technology in Angola, and Africa in general, is large. Also when it comes to smart lighting solutions Africa can make the technology leapfrog. Recent studies, [17], show that Africa were to switch its existing lighting to LED, it could save up to 10 billion dollars in annual energy costs and over 50 million ton of $\mathrm{CO}_{2}$. The focus of the Angolan government is also on load reduction, in order to increase grid reliability. MINEA recently established a project in which 5 million incandescent bulbs are replaced by CLFs. Furthermore the importance of standalone PV LED systems is acknowledged as well, nowadays these systems are already installed on small scale in the suburbs of the major city Luanda. The 2012 budget plan [14] also show the available money for such systems.

\section{CONCLUSION AND DISCUSSION}

In this paper the importance of application of smart grid technologies in developing areas such as Angola, and subSaharan Africa in general, is addressed. The energy strategy in Angola is analyzed, describing the 2025 goal concerning access to electricity, and reviewing the role of the government and the public sector in this context. Furthermore the potential contribution of smart grid technologies to the energy strategy is defined. The country assessment provided in this paper, focusing on the current electrical infrastructure, the energy strategy and the stakeholders active in the power sector, can be used as a first step to develop country specific business models for smart grids in Angola. Also the potential of smart lighting solutions in Angola is analyzed and illustrated, focusing on the current and future contribution of lighting to the total load, the technical impact of lighting on the electricity generation system design, potential economic impact due to energy savings, and social impact due to safe and secure lighting systems. It is shown that installing standalone PV LED systems is a reliable, sustainable and safe way to expand access to lighting. Avoiding technology lockin is crucial in the development of the electricity sector, as the economic lifetime of electric power equipment can be over 50 years [6]. For a successful transition towards smart grids international cooperation is necessary, in order to enable subSaharan Africa to leapfrog traditional power systems practices and move to smart grid elements. Implementing smart grid technologies can accelerate rural electrification and thereby contribute to assuring universal access to energy by 2030 , stimulating development as access to energy is considered a necessary catalyst for development and key factor in poverty reduction.

\section{ACKNOWLEDGMENT}

The authors gratefully acknowledge the contribution of M. Khalil and M. van Twist, from Philips Lighting B.V., for providing essential insights into lighting concepts and for making it possible to perform the field study in Angola.

\section{REFERENCES}

[1] International Finance Cooperation, World Bank Group (2012, May). From Gap to Opportunity: Business Models for Scaling Up Energy Access.

[2] AED (2008). Powering And Empowering Development: Increasing Access to Electricity in Angola.

[3] A.N. Zomers, "Rural Electrification," Ph.D. dissertation, University of Twente, 2001.

[4] G. Upadhyay. (2012, November 09). Smart Grid Application in Developing Countries. ( $1^{\text {st }} \mathrm{ed}$.)

[5] R. Kuwahata, N. Martensen, T. Ackermann, S. Teske, "The Role of Microgrids in Accelerating Energy Access," in Proc. 2012 IEEE PES ISGT Europe Conf, Berlin October 14-17, 2012.

[6] M. Bazilian, M. Welsch, D. Divan, D. Elzinga, G. Strbac, M. Howells, L. Jones, A. Keane, D. Gielen, V.S.K.M. Balijepalli, A. BrewHammond, K. Yumkella, "Smart and Just Grids: Opportunities for subSaharan Africa," Imperial College Londen, Oct. 2011.

[7] S. Jacobs, "Angola, Rise of a new African superpower?," African Business, pg. 48, June, 2012.

[8] N. Pushak, V. Foster. (2011, March). Angola's Infrastructure: A Continental Perspective. AICD, Africa Infrastructure Country Diagnostic.

[9] AICD. Interactive Infrastructure Atlas for Angola. [online]. Available: http://www.infrastructureafrica.org/library/doc/698/angola-interactiveinfrastructure-atlas

[10] G. Magombo, "Southern African Development Community (SADC) POWER Sector Review and Consultation Mission to Angola," AECOM International Development, Gaborone, Botswana, Tech. Rep. USAID Contract No. 690-M-00-04-00309-00, Dec. 2009.

[11] Republic of Angola, Ministry of Energy And Water (2011, August). The National Energy Security Strategy and Policy.

[12] International Energy Agency, IEA (2006). Angola, Towards An Energy Strategy.

[13] R. Stephen (2009, June). Energy Efficiency Made Simple. Chapter 2.1.: Demand Side Management in South Africa, pg. 23-25.

[14] Republic of Angola, Ministry of Finance (2012). Government Budget for 2012. RESUMO DO PIP DO ÓRG $\tilde{A O}$ POR UNIDADE ORCAMENTAL.

[15] M. Ali, M. Orabi, E. Abdelkarim, J.A.A. Qahouq, A. El Aroudi, "Design and Development of Energy-Free Solar Street LED Light System," in Proc. 2011 IEE PES ISGT Middle East Conf., Jeddah, Dec. 17-20, 2011.

[16] C.K. Lee, S. Li, S.Y.R. Hui, “A Design Methodology for Smart LED Lighting Systems Powered By Weakly Regulated Renewable Power Grids," IEEE Transactions on Smart Grid, vol. 2., No. 3., Sep.2011.

[17] Philips (2012, May). The LED lighting revolution, a summary of the global savings potential. [online]. Available: http://www.lighting.philips.com/pwc_li/main/connect/Assets/toolsliterature/LED-lighting-revolution-booklet.pdf, http://ledsmagazine.com/news/9/6/21 